\title{
KSIĄŻKI Z KSIĘGOZBIORU KORDULI $Z$ KOMOROWSKICH POTOCKIEJ W BIBLIOTECE HELENY DĄBCZAŃSKIEJ
}

Przed laty w „Roczniku Biblioteki Polskiej Akademii Nauk w Krakowie” ukazał się Pamiętnik Heleny Dąbczańskiej (1863-1956) w opracowaniu Józefa Fijałka ${ }^{1}$. Autorka wspomnień była lwowską kolekcjonerką, dziś prawie zapomnianą. Znaczną część życia spędziła we Lwowie, w domu przy ulicy Cytadelnej 3, nazwanej później jej imieniem. Życie poświęciła zbieraniu książek, obrazów i rysunków, mebli, porcelany, monet, tkanin oraz innych przedmiotów artystycznych. Wychowana w atmosferze patriotyzmu, jak wielu jej współczesnych, chciała przechować pamiątki polskiej kultury dla przyszłych pokoleń. W swoim muzeum przyjmowała gości, także spoza Lwowa, których chętnie oprowadzała po zbiorach. W 1920 r. przeprowadziła się do Krakowa i zamieszkała na Wawelu, w mieszkaniu wynajętym jej przez władze miasta. Helena Dąbczańska powracała do Lwowa wielokrotnie, tam zastała ją II wojna światowa. W 1946 r. ponownie zamieszkała w Krakowie. Zmarła w Zakładzie Helclów w wieku 93 lat, pochowano ją na koszt miasta na cmentarzu Rakowickim².

Jeszcze za życia większość swoich zbiorów przeznaczyła dla kilku muzeów. Najhojniej obdarzyła Muzeum Narodowe w Krakowie, którego sprawami żyli Polacy trzech zaborów. Od 1906 r. przesyłała sukcesywnie na Wawel książki i inne dzieła sztuki, które miały być udostępniane jako odrębna kolekcja Fundacji im. Dąbczańskich $^{3}$. Kiedy w 1920 r. Dąbczańska przyjechała do Krakowa, zastała swoje dary niszczejące w salach po austriackim szpitalu garnizonowym. Kolekcjonerka, chcąc zapobiec dalszym zniszczeniom, rozdzieliła je między instytucje i osoby prywatne.

\footnotetext{
${ }^{1}$ H. Dąbczańska, Pamiętnik, „Rocznik Biblioteki Polskiej Akademii Nauk w Krakowie”, R. 9: 1963, s. 307-360.

2 J. Fijałek, Dąbczańska Helena [w:] Słownik pracowników książki polskiej [dalej: SPKP], pod red. I. Treichel, Warszawa-Lódź 1972, s. 161.

${ }^{3}$ Korespondencja Heleny Dąbczańskiej z lat 1905-1923, Zakład Narodowy im. Ossolińskich we Wrocławiu, sygn. 11 996/I, s. 3.
} 
Część książek - 10634 tomy przekazała w 1922 r. Bibliotece Muzeum Przemysłowego im. Adriana Baranieckiego w Krakowie, która w następnych latach stała się podstawą Biblioteki Głównej Akademii Sztuk Pięknych im. Jana Matejki. W latach pięćdziesiątych ubiegłego wieku Biblioteka ASP z powodu trudności lokalowych przekazała Bibliotece Jagiellońskiej ok. 1000 książek z księgozbioru Dąbczańskiej.

Książki Heleny Dąbczańskiej znajdujące się w Bibliotece Głównej ASP i Bibliotece Jagiellońskiej (5957 tytułów) zostały przebadane według wielu kryteriów ${ }^{4}$. Poznanie proweniencji pozwoliło m.in. stwierdzić, ile w księgozbiorze zachowało się pozycji z dawnych bibliotek rodowych wymienianych w opisach księgozbioru Dąbczańskiej, świadczą one bowiem o jego wartości ${ }^{5}$. Dąbczańska posiadała książki z bibliotek: Jana Wincentego Bąkowskiego z Ujścia Zielonego, Ludwika i Antoniny Radziwiłłów z Zagrobeli k. Tarnopola, a także Mniszchów. Wśród publikacji należących do Radziwiłłów znalazły się fragmenty ze zbiorów Krosnowskich, generała Jana de Wittego i jego syna oraz Korduli Potockiej. Obecnie egzemplarze z wymienionych zbiorów nie są już bardzo liczne. Z biblioteki Korduli Potockiej zachowało się 90 pozycji, które omówimy w niniejszym artykule.

Kordula Potocka (1764-po 1837) żyła na przełomie dwóch stuleci, XVIII i XIX. W dziejach kultury, także polskiej, to czas schyłku oświecenia i początek romantyzmu. W tamtym czasie właścicielami bibliotek i czytelnikami książek byli przede wszystkim mężczyźni. Zainteresowanie książką wśród kobiet zaczęło wzrastać w XVIII wieku, zwłaszcza w drugiej jego połowie ${ }^{6}$. Panie nie tylko coraz więcej czytały, ale tworzyły również własne księgozbiory. Anna Żbikowska-Migoń stwierdziła, że dokonała się wówczas emancypacja kobiet pod względem upowszechniania książki ${ }^{7}$. W kulturze czytelniczej także nastąpiły zmiany, awansowały lektury rozrywkowe i gatunki uważane dotychczas za niskie ${ }^{8}$. Rozwinęły się epickie odmiany utworów. Obok romansu krytykowanego w okresie oświecenia za bajeczność, powstawały powieści dydaktyczne, propagujące wzorce moralne, ukazujące istotne zjawiska społeczne na realistycznym tle ${ }^{9}$. Fikcję powieściową starano się uwierzytelnić przez posługiwanie się formą pamiętnika, biografii, relacji z podróży, opowiadaniem naocznego świadka, zbiorem listów i innych. Jednak dopiero w XIX w. powieść okazała się gatunkiem najbardziej żywotnym i dynamicznie się rozwijającym. Znalazło to wyraz w mnogości jej typów i odmian ${ }^{10}$. Na początku tego stulecia pod

${ }^{4}$ I. Gruchała, „Lwowski księgozbiór Heleny Dąbczańskiej (1863-1956) jako wyraz kultury książki epoki”, maszynopis pracy doktorskiej, Kraków 2015.

${ }^{5}$ H. Dąbczańska, op. cit., s. 317-318, 320-321; J. Fijałek, op. cit., s. 161.

${ }^{6}$ A. Żbikowska-Migoń, Dzieje książi i jej społecznych funkcji. Wiek VIII, Wrocław 1987, s. 113.

7 Tamże, s. 104.

${ }^{8}$ A. Żbikowska-Migoń, Historia książki w XVIII w., Warszawa 1989, s. 18.

9 Z. Sinko, Powieść [w:] Stownik literatury polskiego oświecenia, red. T. Kostkiewiczowa, Wrocław 1977, s. 524-533.

${ }^{10}$ J. Bachórz, Powieść [w:] Stownik literatury polskiej XIX wieku, red. J. Bachórz, A. Kowalczykowa, Wrocław 2002, s. 733-748. 
wpływem sentymentalizmu nadal powstawały romanse; ukształtowała się powieść historyczna oparta na modelu wykreowanym przez Waltera Scotta; rozwijała się powieść obyczajowa wzorowana na twórczości Laurence’a Sterne’a; kierunek realistyczny w prozie wytyczały utwory Balzaka i Stendhala.

Zjawiska te znalazły odbicie w zawartości prywatnych bibliotek. W księgozbiorach dam modnych procentowy udział romansów w całości księgozbioru wynosił od 20 do $82 \%{ }^{11}$. Ulubionymi lekturami pań, według Mieczysława Klimowicza, były powieści sentymentalne: Cierpienia młodego Wertera Johanna Wolfganga Goethego, Nowa Heloiza Jean'a Jacques'a Rousseau oraz Pamela Samuela Richardsona $^{12}$. W bibliotekach magnackich i dam modnych powieści w polskim thumaczeniu należały do rzadkości; czytano po francusku, czasami po angielsku lub włosku ${ }^{13}$. Na początku następnego wieku nadal bardzo ceniono powieść francuską $\mathrm{i}$ angielską. Z literatury francuskiej wielkim powodzeniem cieszyły się romanse Paula de Kocka, Eugène'a Sue'a, a także powieści Honoré de Balzaca i George Sand ${ }^{14}$. Natomiast $\mathrm{z}$ literatury angielskiej znano w Polsce twórczość George Byrona, Waltera Scotta, a za najbardziej reprezentatywne dla współczesności uznawano powieści Edwarda Bulwer Lyttona oraz pisarza marynistycznego Fredericka Marrayata ${ }^{15}$. Przed romantycznym przełomem w Polsce nastąpił okres wzrostu zainteresowania powieścią gotycką, w której wykorzystywano tematykę historyczną, sentymentalną, fantastyczną, erotyczną i inną.

Anna Żbikowska-Migoń stwierdziła, że pod koniec XVIII stulecia przybyło kobiet światłych i wykształconych. Powieści nie były już jedynymi lekturami pań ${ }^{16}$. Gromadziły one także ilustrowane czasopisma, almanachy, słowniki i encyklopedie. Tworzyły nawet specjalistyczne księgozbiory ${ }^{17}$. Zjawisko to potwierdzają informacje o bibliotekach założonych w czasach Korduli Potockiej. Nadal najwięcej księgozbiorów powstawało wśród kobiet zamożnych. Własne księgozbiory zgromadziła Helena Radziwiłł (1752-1821) w Arkadii i Nieborowie ${ }^{18}$. Składały się one z dzieł obcojęzycznych, z zakresu historii, prawa, filozofii, sztuki ogrodniczej i literatury. Wśród literatury klasycznej i francuskiej przeważały utwory sentymentalne. Elżbieta

${ }^{11}$ Z. Sinko, Powieść zachodnioeuropejska w kulturze literackiej polskiego oświecenia, Wrocław 1968, s. 139.

12 M. Klimowicz, Oświecenie, Warszawa 1999, s. 285.

13 Z. Sinko, Powieść zachodnioeuropejska w Polsce stanistawowskiej na podstawie inwentarzy i bibliotecznych i katalogów, „Pamiętnik Literacki” 1966, R. 57, z. 3, s. 581-624.

${ }^{14}$ A. Kowalczykowa, Francusko-polskie zwiazki literackie [w:] Stownik literatury polskiej XIX wieku, red. J. Bachórz, A. Kowalczykowa, Wrocław 2002, s. 309.

${ }^{15}$ W. Krajewska, Angielsko-polskie zwiazki literackie [w:] Stownik literatury polskiej XIX wieku..., s. 22-26.

16 A. Żbikowska-Migoń, Dzieje ksią̇ki i jej funkcji..., s. 113.

17 Marianna z Szyndlerów, właścicielka dużej apteki w Warszawie miała zbiór, w którym przeważały książki medyczne i farmaceutyczne, zob. Z. Goliński, Biblioteki i czytelnictwo [w:] Słownik literatury polskiego oświecenia, red. T. Kostkiewiczowa, Wrocław 1977, s. 37.

18 J. Wegner, Radziwiłt [w:] SPKP, Warszawa-Łódź 1972, s. 740-741. 
Izabella Lubomirska (1733-1816) kolekcjonowała dzieła sztuki i zbierała książki ${ }^{19}$. Podobnie jak mąż, Stanisław, miała jedną bibliotekę w Lańcucie, drugą w pałacu w Mokotowie. Jej księgozbiór zawierał głównie dzieła francuskie. W czasie pobytu za granicą zebrała dużo wydawnictw muzycznych, które następnie sprowadziła do Łańcuta. Książkami muzycznymi interesowała się również Teresa Lubomirska z Czartoryskich (1785-1868), żona Henryka, pierwszego kuratora Zakładu Narodowego im. Ossolińskich ${ }^{20}$. W Przeworsku jej biblioteka muzyczna liczyła około 900 pozycji nut, głównie kompozytorów z końca XVIII wieku. Z kolei Izabela Czartoryska (1746-1835), organizatorka życia kulturalnego i literackiego, w swojej rezydencji w Powązkach koło Warszawy, zgromadziła nieduży księgozbiór, złożony z doborowych dzieł poetyckich i wydawnictw ilustrowanych polskich i zagranicznych ${ }^{21}$. W roku 1794, po upadku powstania kościuszkowskiego, został on zdewastowany, a część książek wywieziono do Rosji. Czartoryska w następnych latach zebrała cenny zbiór inkunabułów i rękopisów. W tworzeniu księgozbioru rodowego Raczyńskich pomagała Konstancja (1781-1859), żona Edwarda Raczyńskiego ${ }^{22}$. Zakupiła około 1680 pozycji ze zbiorów poety Juliana Ursyna Niemcewicza z Ursynowa pod Warszawą i osobiście przewiozła je do Rogalina. W tej kolekcji znalazły się m.in. mapy, atlasy i rękopisy. Przykładem księgozbiorów gromadzonych przez mieszkanki dużych miast mogą być biblioteki Józefy Gostkowskiej (1760-1850) i Antoniny Krechowieckiej (1791-1831). Starannie wykształcona Gostkowska systematycznie gromadziła w Krakowie przy ulicy Brackiej współczesne wydawnictwa, głównie o tematyce historyczno-literackiej, w większości w języku francuskim $^{23}$. Krechowiecka była lwowską publicystką i pisarką. Zebrała w domu 275 dzieł, najwięcej w języku francuskim i niewiele w języku polskim i niemieckim $^{24}$.

O bibliofilstwie kobiet tego okresu wiemy coraz więcej. Nazwiska właścicielek księgozbiorów wymieniają prace monograficzne takie, jak: Książi i biblioteki w Polsce okresu zaborów Kazimiery Maleczyńskiej ${ }^{25}$ oraz Księgozbiory domowe $w$ Galicji Wschodniej (1772-1918) Józefa Szockiego ${ }^{26}$. Z szerszej perspektywy dziejowej ukazała to zagadnienie Hanna Tadeusiewicz w artykule zatytułowanym Bibliofilskie zamiłowania Polek. Właścicielki bibliotek $w$ dawnej Polsce (XIII-

19 J. Długosz, Lubomirski Stanisław [w:] SPKP, Warszawa-Łódź 1972, s. 528.

20 Tamże, s. 526.

21 T. Frączyk, Czartoryski Adam Kazimierz [w:] SPKP, Warszawa-Lódź 1972, s. 143-144.

${ }^{22}$ A. Wojtkowski, J. Zaręba, Raczyński Edward [w:] SPKP, Warszawa-Lódź 1972, s. 736 .

${ }^{23}$ A. Lewicka-Kamińska, Gostkowska Józefa [w:] Polski Stownik Biograficzny [dalej: PSB]. T. 8, Wrocław 1959-1960, s. 359.

${ }^{24}$ J. Szocki, Księgozbiory domowe w Galicji Wschodniej (1772-1918), Kraków 2001, s. 240 .

${ }^{25}$ K. Maleczyńska, Książki i biblioteki w Polsce okresu zaborów, Wrocław 1987, s. 220 221.

${ }^{26}$ J. Szocki, op. cit. 
$X I X$ w. ${ }^{27}$. Sylwetki miłośniczek książek poznajemy również z kart Polskiego Słownika Biograficznego oraz Stownika pracowników książki polskiej. W wymienionych wydawnictwach opisy księgozbiorów są bardzo ogólne. Szczegółowe informacje o bibliotece prywatnej występują na ogół w publikacjach przedstawiających wyniki badań nad księgozbiorem indywidualnym. W ostatnich latach dość często są one oparte na badaniach proweniencyjnych prowadzonych w różnych instytucjach. Pozwalają one wyodrębnić książki pochodzące z dawnej biblioteki i ożywić ich opisy przez podanie autorów i tytułów dzieł oraz innych cech indywidualnych. Przykładem takiej pracy jest artykuł Grażyny Rolak ukazujący Fragment księgozbioru Józefiny Potockiej w zbiorach $\mathrm{ZNiO}^{28}$. Józefina Amelia Potocka była postacią znaną w epoce stanisławowskiej, poświęcono jej biogram w $P S B^{29}$, jednak opis książek z jej biblioteki jest swoistą wizytówką osoby i epoki, w której żyła ${ }^{30}$. Kordula Potocka, o której książkach będzie mowa w niniejszym artykule, jest obecnie postacią zapomnianą. Ufamy jednak, że ta drobna praca również w istotny sposób uzupełni obraz bibliofilstwa kobiet żyjących na przełomie XVIII i XIX stulecia.

Kordula Potocka wywodziła się ze znakomitego rodu Komorowskich. Jej ojcem był Jakub Komorowski (1697-1781) kasztelan santocki i senator. Miała kilkoro rodzeństwa, a z nich najbardziej znana jest jej siostra Gertruda, która poślubiwszy potajemnie Szczęsnego Potockiego zginęła w tajemniczych okolicznościach. Sprawa ta przez wiele lat powracała na forum publiczne, bo ojciec łudził się, że córka żyje i szukał sprawiedliwości u króla. Tragiczne to wydarzenie stało się tematem kilku utworów literackich ${ }^{31}$, ale też przysłoniło postacie innych dzieci Komorowskiego. O Korduli pisze się z okazji jej ślubu w 1788 r. z Teodorem Potockim (1730-1812) herbu Pilawa ${ }^{32}$. Reprezentował on tzw. lwowską gałąz rodu Potockich. Posiadał kilka miast i kilkadziesiąt wsi. Był posłem, konfederatem barskim, generałem-majorem wojsk koronnych oraz wojewodą bełskim, a od 1809 roku prezesem Rządu Tymczasowego Galicji. Zapamiętano go także jako przeciwnika Konstytucji 3 Maja. Poślubił Kordulę po rozwodzie z pierwszą żoną Karoliną Sapieżanką, z którą miał syna Adama. Pomimo dużej różnicy wieku małżeństwo było bardzo udane. Kordula Potocka była znana z piękności i brylantów ogromnej wartości, które podarował jej mąż po sprzedaniu miejscowości Gródek ${ }^{33}$. Brylanty te sławne były nie tylko

${ }^{27}$ H. Tadeusiewicz, Bibliofilskie zamiłowania Polek. Wtaścicielki bibliotek $w$ dawnej Polsce (XIII-XIX w.) [w:] Ksiażka, biblioteka, informacja w kręgu kultury i edukacji, red. E. B. Zybert, D. Grabowska, Warszawa 2008, s. 19-27.

${ }^{28}$ G. Rolak, Fragment księgozbioru Józefiny z Mniszchów Potockiej w zbiorach Działu Starych Druków ZNiO, „Czasopismo Zakładu Narodowego im. Ossolińskich” 2002, z. 13, s. 137-176.

${ }^{29}$ M. Czeppe, Potocka z Mniszchów Józefina Amelia [w:] PSB. T. 27, Wrocław 1982, s. $740-742$.

${ }^{30}$ G. Rolak, op. cit., s. 139.

${ }^{31}$ Najsłynniejsza była powieść poetycka Maria (1825) Antoniego Malczewskiego; powstały też powieści: Gertruda Komorowska (1853) Marii Pomezańskiej z Chłędowskich oraz Starościna betska (1858) Józefa Ignacego Kraszewskiego.

32 W. Szczygielski, Potocki Teodor [w:] PSB. T. 28, Wrocław 1984-1985, s. 213-216.

${ }^{33}$ K. Nakwaska, Pamiętnik o Adamie hr. Potockim, Kraków 1862, s. 6. 
w kraju, ale także we Wiedniu i nadały jej przydomek de Fée Diamantine [Diamentowa Czarodziejka].

Główną rezydencją Potockiego był Smotrycz na Podolu, ale małżonkowie zmieniali miejsca zamieszkania. Karolina Nakwaska, wnuczka Teodora Potockiego, wspominała w pamiętniku poświęconym swemu ojcu Adamowi, że jej dziad lubił życie dworne i hojnie podejmował gości. We dworze w Sawińcach mieszkało wiele osób z rodziny, utrzymywał tam marszałka dworu, kilkunastu muzykantów, dwanaście hafciarek dla żony, panny stołowe i wiele innej służby. Kordula Potocka musiała interesować się literaturą, skoro jej mąż umieszczał wiersze na alabastrowych kolumnach w różnych częściach ogrodu, żeby jej sprawić przyjemność ${ }^{34}$.

Jednak życie małżonków nie upływało tylko na zabawie. Teodor Potocki był ważną postacią $\mathrm{W}$ życiu politycznym kraju. W niektórych poczynaniach towarzyszyła mu żona. W roku 1796 udała się z mężem do Petersburga, aby razem z innymi członkami polskiej delegacji prosić Katarzynę II o wypuszczenie z więzienia Tadeusza Kościuszki, Ignacego Potockiego, Juliana Ursyna Niemcewicza i innych. Wyprawa przybyła w szczególnym momencie: cesarzowa właśnie zmarła, a nowy imperator był tak wzruszony złożonym mu po raz pierwszy hołdem, że więźniów uwolnił. Kordula Potocka bywała także na dworze austriackim. W 1799 r. została damą Krzyża Gwiaździstego, ustanowionego przez cesarzową Eleonorę. Potocką spotkało jeszcze jedno wyróżnienie: nadano jej godność damy pałacowej. W Austrii dostępowały tego zaszczytu członkinie wielkich rodów szlacheckich i małżonki najwyższych urzędników państwowych ${ }^{35}$.

Potoccy posiadali we Lwowie mały pałacyk zawsze otwarty dla gości. Odwiedzał ich młody Aleksander Fredro, by po latach tak to wspominać: „W domu województwa, a potem wojewodziny, nudzono się zwykle, lecz jednak bywano. Co dzień wieczór można było kogo zastać i kto tylko przyjechał lub przejeżdżał przez Lwów, szedł tam, gdzie zawsze przyjmowali, gdzie ziewali, ale w dobrym towarzystwie" ${ }^{36}$. Kordula Potocka, jak wiele pań z jej sfery, zajmowała się dobroczynnością, była inicjatorką Towarzystwa Dobroczynności dla opieki nad biednymi ${ }^{37}$. W czasie wojny Napoleona z Austrią w 1809 r. siedziba Potockich była miejscem spotkań i narad okolicznej szlachty. Wojska polskie wkroczyły do Lwowa w maju 1809 r. i z tym wydarzeniem związana jest anegdota, której bohaterką jest Potocka. 28 maja do miasta przybył większy oddział żołnierzy pod wodzą generała Aleksandra Rożniewskiego. Miasto powitało go dźwiękiem dzwonów i okrzykami radości. Kordula Potocka na oczach tłumu owinęła własnym szalem ranę koniowi porucznika Jerzego Starzeńskiego i pocałowała rumaka ${ }^{38}$. Kilka lat po tych wydarzeniach zmarł Teodor Potocki, jego żona żyła znacznie dłużej, zmarła ok. 1837 r., jednak jej dalsze losy pozostają dotychczas nieznane.

34 Tamże, s. 12.

35 J. S. Dunin-Borkowski, Panie polskie przy dworze rakuskim, Lwów 1891, s. 142.

36 A. Fredro, Trzy po trzy, Kraków 1949, s. 171.

37 L. Podhorodecki, Dzieje Lwowa, Warszawa 1993, s. 108.

38 Tamże, s. 103. 
Książki należące niegdyś do Korduli Potockiej, a obecnie znajdujące się w Bibliotece Głównej Akademii Sztuk Pięknych w Krakowie i Bibliotece Jagiellońskiej, wyodrębniono z księgozbioru H. Dąbczańskiej na podstawie znaków własnościowych. Wszystkie egzemplarze na dole grzbietu posiadają kolorowe nalepki z napisami: Comtesse Cordula Potocka, Comtesse Cordelia Potocka, Comtessa Potocka oraz Cordule Comtesse Potocka. W czterech egzemplarzach wystąpił ręczny podpis właścicielki, która na stronach tytułowych napisała piórem: Cordule Potocka; appartient à Cordula C: Potocka; K P oraz Cordelie Comtesse Potocka née Comtesse Komorowska. Oprawy zostały wykonane z tektury oblepionej brązowym, marmurkowym papierem w ciemniejszym odcieniu na grzbiecie. Książki ustawione na półce robią wrażenie bogato oprawionych. Sprawia to kolor papieru imitujący skórę i nalepki w kolorach: beżowym, niebieskim i czerwonym, często zdobione złoceniami.

Analiza cech wydawniczo-formalnych książek Korduli Potockiej pokazuje, że wszystkie zostały wydane za granicą; aż $81 \mathrm{w}$ Paryżu. Zasięg chronologiczny biblioteki zamyka się w latach 1788-1834, jednak książek z końca XVIII w. jest zaledwie 8, natomiast dominują publikacje z lat 20. i 30. XIX w. -64 pozycje. Wszystkie książki są w języku francuskim; 70 dzieł zostało napisanych w tym języku, a 20 przetłumaczono z innych języków (angielskiego, niemieckiego, włoskiego i chińskiego).

Wśród książek Korduli Potockiej największą grupę tworzą utwory literackie. Reprezentują one głównie literaturę francuską, ale spotykamy również dzieła należące do literatury angielskiej, niemieckiej, amerykańskiej i innych. Niewiele jest między nimi gatunków poetyckich i dramatycznych, dominują natomiast różne odmiany prozatorskie. Między powieściami obyczajowymi zwraca uwagę książka Alain-René Lesage'a pt. Histoire de Gil Blas de Santillane (Wiedeń, 1812), wielki bestseller epoki oświecenia. Autor wykorzystał wątek awanturniczego życia bohatera do ukazania satyrycznego obrazu społeczeństwa. Dzieło to osiągało wysokie nakłady we Francji ${ }^{39}$, było też wydawane w innych krajach. W Polsce Lesage uznawany był za najwybitniejszego z pisarzy europejskich, jego twórczość propagowano na łamach „Monitora” ${ }^{40}$. Inne powieści obyczajowe, które posiadała Kordula Potocka powstały w jej czasach. Należy do nich Le Médecin de campagne (Paryż, 1833) Honoré de Balzaca. Utwór ten zalicza się do cyklu Sceny z życia prywatnego, pochodzi z okresu, kiedy Balzac zainteresował się życiem na prowincji. Dwie powieści George Sand: Indiana (Paryż 1832) oraz Lélia (Paryż, 1833) poruszają problemy obyczajowej emancypacji kobiet. Francuska pisarka przedstawiła w nich radykalne propozycje rozwiązania kwestii kobiecej. Poglądy George Sand miały wpływ na ruch emancypacyjny w Polsce. Książki Balzaca i Sand to pierwsze wydania tych utworów. Powieści obyczajowe pisał również James Fenimore Cooper.

${ }^{39}$ E. Zawisza, Drukarze a powieść we Francji XVIII wieku, „Studia o Książce” 1983, T. 13, s. 59.

${ }^{40}$ Z. Sinko, Powieść [w:] Stownik literatury polskiego oświecenia..., s. 525. 
Potocka posiadała m.in. francuskie wydanie Précaution, ou Le Choix d'un mari (Paryż 1825), pierwszej powieści amerykańskiego pisarza wzorowanej na twórczości Jane Austen ${ }^{41}$. Ta konwencjonalna powieść z życia angielskiego ziemiaństwa dała początek wielkiej karierze pisarskiej Coopera. Wymienieni pisarze znaleźli trwałe miejsce w historii literatury, ale w bibliotece Potockiej jest też wiele utworów drugorzędnych, dzisiaj zupełnie zapomnianych. Przykładem takiej twórczości jest powieść Auguste'a Ricarda Le Cocher de fiacre, ou Quarante ans sur le pavé de Paris (Paris 1828). Ricard był autorem bardzo popularnych sztuk teatralnych, natomiast w powieściach ukazywał środowiska charakterystyczne dla Francji I połowy XIX w.

Do Korduli Potockiej należało wiele utworów o tematyce historycznej, w formie charakterystycznej dla początku XIX w., kiedy kształtowała się powieść historyczna $^{42}$. Książka brytyjskiej pisarki Mary Hamilton La Famille du duc de Popoli. Mémoires de M. de Cantelmo, son frère (Wiedeń 1818) została wydana po raz pierwszy w 1810 r. ${ }^{43}$ Hamilton, której pisarstwo miało wpływ na twórczość Jane Austen, przedstawiła w niej dzieje szlacheckiej rodziny Catelmo z włoskiej miejscowości Popoli. Forma pamiętnika miała świadczyć o autentyczności opisywanych wydarzeń i sprawiać wrażenie, w odbiorze czytelniczym, obcowania z autentycznym dokumentem. Pamiętniki z życia dworu Lucy Aikin, należącej już do następnego pokolenia pisarek brytyjskich, zbliżały się do pozaliterackich opracowań historycznych ${ }^{44}$. Kordula Potocka posiadała jedną z jej najsłynniejszych prac pt. Mémoires sur la cour d'Élisabeth (Paryż, 1827). Utwór ten stał się wzorem dla innych autorów. Niemiecki pisarz Carl Franz van der Velde chcąc zaznaczyć autentyczność opisywanych zdarzeń powoływał się w swoich powieściach na kroniki z XVI w. Mówią o tym uzupełnienia do tytułów w paryskich wydaniach jego książek: Les Patriciens. Histoire de la fin du XVIe siècle, d'après d'anciennes chroniques (1826) oraz Les Anabaptistes. Histoire du commencement du XVI siècle, d'après les chroniques et les documents du temps (1826). Nowoczesną formę powieści historycznej nadał Walter Scott, a jego pisarstwo nawiązywało do jeszcze innej odmiany gatunku powieściowego - powieści przygodowej. W czasach Korduli Potockiej jego twórczość była bardzo popularna w Polsce, poznawano ją z przekładów francuskich. Chwalono Scotta za humor i pogodę jego powieści, a także za ukazywanie wzorów szlachetności i patriotyzmu. Książki tego autora, zachowane w bibliotece Potockiej, nie należą do tych najsłynniejszych, najbardziej znanych. Historycy literatury podzielili powieści Scotta na grupy tematyczne ${ }^{45}$. Stosując to kryterium powieść

${ }^{41}$ A. Kopcewicz, M. Sienicka, Historia literatury amerykańskiej w zarysie. Wiek XVII-XIX, Warszawa 1983, s. 172.

${ }^{42}$ T. Bujnicki, M. Czermińska, Powieść historyczna [w:] Literatura polska. Przewodnik encyklopedyczny. T. 2, red. Cz. Hernas, Warszawa 1985, s. 217-219.

${ }^{43}$ L. Sage, The Cambridge guide to women's writing in English, Cambridge 1999, s. 302.

${ }^{44}$ British autors of the nineteenth century, ed. by Stanley J. Kunitz, New York 1936, s. 6.

${ }^{45}$ H. Zbierski, Literatura angielska [w:] Dzieje literatur europejskich. T. 2, red. W. Floryan, Warszawa 1982, s. 459-460. 
Histoire d'Écosse racontée par un grand-père à son petit-fils [...] (Paryż, 1828) należy do utworów ukazujących dzieje Szkocji do XVIII w., książka Woodstock (Paryż, 1826) mieści się w grupie mówiącej o historii Anglii, natomiast pozycja pt. Charles le Téméraire ou Anne de Geierstein, la fille du brouillard (Paryż, 1829) zalicza się do publikacji ukazujących historię innych państw. W Polsce ceniono również powieści Edwarda Bulwer Lyttona ${ }^{46}$, którego twórczość była bardzo różnorodna. W jego dorobku znajdują się też utwory historyczne. Potocka posiadała trzytomową powieść Devereux wydaną w Paryżu w 1829 r. Tłem dla opisywanych wydarzeń są czasy panowania Anny Stuart, królowej Anglii i Szkocji, a od 1707 r. Wielkiej Brytanii. Utwór ten po raz pierwszy został wydany w Londynie również w 1829 r., czyli bardzo szybko został przetłumaczony na język francuski i trafił do polskiego księgozbioru.

Wśród książek Korduli Potockiej nie mogło zabraknąć pozycji zawierających historie miłosne. Przykładem powieści sentymentalnej w listach jest pierwsze wydanie Delphine (Paryż 1802) napisanej przez Germaine de Staël-Holstein, znanej jako pani de Staël. Fabuła powieści wpisuje się w schemat tego gatunku powieściowego. Tytułowa bohaterka przeżywa nieszczęśliwą miłość do mężczyzny, który poślubia inną kobietę. Trudną sytuację rozwiązuje szlachetnie - popełnia samobójstwo. W powieści tej szczególnie gustowały panie stawiające większe wymagania tego typu literaturze ${ }^{47}$. W zupełnie innej konwencji perypetie miłosne ukazywali inni, dzisiaj zapomniani pisarze. Czterotomowa powieść Les Forges mystérieuses, ou L'Amour alchymiste (Paryż, 1800-1801) francuskiej pisarki Élisabeth Brossin de Méré określana jest jako frywolna, czy nawet rozwiązła ${ }^{48}$. Autorka ukryła swoje nazwisko pod pseudonimem: Guénard de Faverolle, niegdyś kapitan dragonów. Również książka Richarda Cumberlanda Arundel (Paryż 1798) cieszyła się złą sławą. Brytyjski komediopisarz napisał zaledwie trzy powieści, a z encyklopedii Samuela Orgelbranda dowiadujemy, że pomimo znakomitego stylu, „niedobrze były przyjęte z powodu jawnego usiłowania ku rehabilitacji występku" ${ }^{49}$.

U schyłku oświecenia i w początkowym okresie romantyzmu bardzo modne były w literaturze tematy wschodnie. Od końca XVIII w. rozwijała się filologia orientalna i archeologia, co przyczyniło się do przetłumaczenia na język francuski lub angielski wielu utworów ${ }^{50}$. W bibliotece Korduli Potockiej znajdują się trzy tomy chińskich opowieści Contes chinois (Paryż, 1827) przełożonych na francuski przez Johna Francisa Davisa, Petera Perringa Thomsa oraz François Xavier Den-

${ }^{46}$ W. Krajewska, Angielsko-polskie zwiazki literackie [w:] Stownik literatury polskiej XIX wie$k u \ldots$, s. 25.

${ }^{47}$ K. Falicka, Literatura francuska. Wiek XIX [w:] Dzieje literatur europejskich. T. 1, red. W. Floryan, Warszawa 1977, s. 717.

${ }^{48}$ Vivre libre et écrire. Anthologie des romancirès de la période révolutionnaire (1789-1800), textes choisis et présentés H. Krief, Oxford-Paris, 2005, s. 284, dostęp: https://books.google.pl/books?id=ERty_FkILNIC\&pg=PA314\&Ip, odczyt: 15 grudnia 2015.

49 Encyklopedia powszechna. T. 6, Warszawa 1861, s. 3-4.

${ }^{50}$ M. Piwińska, Orientalizm [w:] Stownik literatury polskiej XIX wieku..., s. 655. 
trecollesa. Opracowania edytorskiego dokonał Abel Rémusat, orientalista, profesor języka i literatury chińskiej w Colège de France. Bajki wschodnie i motywy orientalne inspirowały romantycznych pisarzy, którzy przetwarzali je w indywidualny sposób. Przykładem takiej twórczości są książki hrabiego Adriena de Sarazin, np. Le Caravansérail, ou Recueil de contes orientaux traduit sur un manuscrit persan (Paryż, 1825).

Wśród nielicznych utworów poetyckich na uwagę zasługują wydania poezji opisowej Jacques'a Delille'a, przedstawiciela klasycystycznego nurtu poezji oświeceniowej, bardzo popularnego w kręgach ośrodka puławskiego stworzonego przez Izabelę Czartoryską. Księżna Czartoryska umieściła nawet jego imię na pomniku w parku puławskim wśród innych sielskich poetów, a w Paryżu odwiedzili go: Julian Ursyn Niemcewicz, Grzegorz Piramowicz, Jan Śniadecki i Stanisław Trembecki ${ }^{51}$. Potocka posiadała najwcześniejsze wydania dwóch utworów Delille'a. Poemat L'Homme des champs, ou Les géorgiques françoises ukazał się w Bazylei w 1800 r. Poeta propagował w nim kult wiejskości, którego atrybutami jest życie moralne, czułość i wrażliwość wynikająca ze związku z naturą. Natomiast poemat w ośmiu pieśniach L'Imagination (Paryż 1806) jest jednym z ostatnich dzieł Delille'a. We wstępie poeta wyznał, że w swojej twórczości chciał uwiecznić tajemną i odwieczną zależność, jaką natura ustanowiła między światem fizycznym i duchowym.

Drugą, obszerną grupę tematyczną tworzą dzieła historyczne. Tak można je określić z dzisiejszej perspektywy. Jednak wśród nich jest zaledwie kilka tytułów odnoszących się do bardzo odległych czasów. Szeroki zasięg chronologiczny wyróżnia pracę hrabiego Prospera Brugière Brabante'a. Francuski historyk i polityk w książce Histoire des ducs de Bourgogne de la maison de Valois, 1364-1477 (Paryż 1824-1826) przedstawił dzieje Burgundii, krainy położonej w środkowo-wschodniej Francji, w okresie panowania dynastii Walezjuszy. Publikacja ta jest przykładem romantycznej szkoły historycznej; autor barwnie opowiada o wydarzeniach, unikając jednak ich oceniania. $Z$ trzynastotomowego wydania zachowało się jedynie 10 tomów. Również praca Gabriela Peignota zatytułowana De la Maison royale de France, ou Précis généalogique et anecdotique sur la famille de Bourbon [...], depuis Saint-Arnoul, en 596 [...] (Paris, 1815) obejmuje zagadnienia wielu stuleci. Peignot, literat i bibliotekarz, ceniony jest za dzieła teoretyczne z zakresu bibliografii. Pozycja z biblioteki Korduli Potockiej należy do mniej znanych i świadczy, że Peignot interesował się także historią i chronologią.

Między książkami Korduli Potockiej występuje wiele wydawnictw ukazujących wydarzenia, które rozegrały się jeszcze za jej życia. Ich tematyka dotyczy głównie historii Francji, na którą zwrócone były oczy ówczesnej Europy. Obserwowano przebieg rewolucji francuskiej; wojny rewolucyjnej Francji, a później napoleońskie; obrady Kongresu Wiedeńskiego; próby przywrócenia we Francji porządku przedrewolucyjnego. Autorzy używali różnych form piśmienniczych, których cechy

${ }^{51}$ A. Aleksandrowicz, Izabela Czartoryska, Lublin 1998, s. 68-69. 
dopiero dzisiaj zostały sprecyzowane ${ }^{52}$, a więc nie wchodząc w szczegóły określające gatunki, zauważamy wśród książek pamiętniki, biografie, traktaty polityczne i historyczne, a także relacje osobiste. Wśród prac wspomnieniowych zwraca uwagę dziesięciotomowe wydanie Mémoires inédits de madame la Comtesse de Genlis sur le dix-huitième siècle et la révolution française, depuis 1756 jusqu'à nos jours (Bruksela, 1825) francuskiej pisarki, hrabiny Stéphanie-Félicité Du Crest Genlis. Pani Genlis u schyłku życia opisała epokę, w której żyła, czasy przed rewolucją i zmiany po jej zakończeniu. Sportretowała ludzi, których spotykała, a były wśród nich takie znakomitości jak Rousseau czy Voltaire. A wszystko to zostało napisane językiem żywym i ubarwione licznymi anegdotami. Autorami pamiętników są też osoby dzisiaj już zapomniane, takie jak np. Antonio Galotti, neapolitańczyk, oficer uczestniczący w wielu spiskach karbonariuszy. Jego książka pt. Mémoires de A. Galotti, officier Napolitain, condamné trois fois à mort (Paryż, 1831) przywołuje dramatyczne wydarzenia $\mathrm{z}$ lat 1820-1830. Swoją relację rozpoczął od opisu pobytu w więzieniu, w którym oczekiwał na wyrok śmierci. Wybuch rewolucji w $1820 \mathrm{r}$. w Neapolu na krótki czas przywrócił mu wolność.

$\mathrm{Z}$ prac biograficznych na uwagę zasługuje słownik opracowany przez Société de gens de lettres pt. Biographie étrangère, ou Galerie universelle, historique, civile, militaire, politique et littéraire; contenant les portraits politiques de plus de trois mille personnages célèbres [...] (Paryż, 1819). Przedstawiono w nim sylwetki słynnych cudzoziemców, m.in. Adama Kazimierza Czartoryskiego i jego syna Adama Jerzego oraz Tadeusza Kościuszki. Biografię indywidualną reprezentuje dzieło Waltera Scotta: Vie de Napoléon Buonaparte (Paryż, 1827). Przyczyniło się ono do rozwoju kultu cesarza, ale napisane w dużym pośpiechu zebrało wiele uwag krytycznych. Kordula Potocka posiadała jedną z takich publikacji autorstwa Jean-François Caze'a pt. Réfutation de „La vie de Napoléon” sir Walter Scott (Paryż, 1827). Na temat bieżącej sytuacji we Francji wypowiedział się wielki pisarz francuski François-René de Chateaubriand w książce zatytułowanej De la Nouvelle proposition relative au bannissement de Charles X et de sa famille, ou Suite de mon dernier écrit „De la Restauration et de la monarchie élective” (Paryż, 1831). Poglądy Chateaubrianda miały duży wpływ na historiografię i politykę ${ }^{53}$. Sam pisarz wielokrotnie zmieniał swoje sympatie polityczne. Utwór z biblioteki Potockiej został napisany po rewolucji lipcowej 1830 r., kiedy próba przywrócenia dawnego porządku natrafiła na opór liberalnego mieszczaństwa i zakończyła się detronizacją króla Karola X. Chateaubriand po tych zdarzeniach wycofał się z życia publicznego.

Książki dotyczące innych zagadnień tworzą niewielką grupę. Typową tematykę geograficzną reprezentują prace zawierające opisy podróży lub miasta i jego środowiska. Jedną z nich jest publikacja oficera marynarki brytyjskiej i pisarza, Johna Gabriela Stedmana pt. Voyage à Surinam et dans l'intérieur de la Guiane [...] (Paryż, 1798). Stedman wiele lat po powrocie z Surinamu i Gujany spisał swoje

\footnotetext{
${ }^{52}$ M. Dernałowicz, Pamiętnikarstwo [w:] Stownik literatury polskiej XIX wieku..., s. 670.

53 J. Serczyk, 25 wieków historii. Historycy i ich dzieła, Toruń 1994, s. 251-252.
} 
wrażenia. Jego relacja skupia się na przedstawieniu życia rodowitych mieszkańców tych obszarów, kolonizowanych przez kraje europejskie, opisie obyczajów i różnic kulturowych między nacjami. Z kolei książka pani Genlis: Dictionnaire critique et raisonné des étiquettes de la cour, des usage du monde, des amusemens, des modes, des moeurs [...]. (Paryż, 1818) przedstawia w ujęciu historycznym (od śmierci Ludwika XIII w 1643 r. do czasów współczesnych autorki) zagadnienia związane z życiem dworu królewskiego i jego mieszkańców. Długi tytuł dzieła mówi, że znajdziemy w nim wiadomości o etykiecie dworskiej i zasadach bywania w wielkim w świecie, a także porady, jak się bawić i modnie ubierać. W zupełnie inne obszary tematyczne przenosi czytelnika drugie wydanie dzieła pani de Staël De l'Allemagne (Paryż, 1814), które zapewniło jej trwałe miejsce w historii literatury ${ }^{54}$. W obszernej rozprawie autorka ukazała wyidealizowany obraz kultury i literatury niemieckiej; wyraziła oryginalne i nowe na gruncie francuskim poglądy na literaturę, sztukę, filozofię, religię i obyczaje. Praca jest pochwałą literatury romantycznej, której źródłem powinien być entuzjazm i natchnienie. Na uwagę zasługuje również pierwsze wydanie pracy zatytułowanej Histoire de la vie et des ouvrages de Molière (Paryż, 1825). Francuski literat i polityk, Jules-Antoine Taschereau, omówił w niej koleje życia i utwory Molière'a, siedemnastowiecznego komediopisarza. Tego typu opracowania monograficzne są charakterystyczne dla historii literatury, której podstawy kształtowały się w XIX w.

W książkach Korduli Potockiej odnajdujemy przejawy zjawisk, które były charakterystyczne dla kultury jej czasów. Jako dama modna i żona wielkiego magnata czytała książki po francusku, wydane za granicą. Brak wśród nich dzieł polskich autorów, nawet nosząca polskie nazwisko Franciszka Trembicka uchodzi za pisarkę francuską ${ }^{55}$. Zbiór książek Potockiej ma charakter humanistyczny, podobnie jak większość księgozbiorów prywatnych czasu zaborów, przeważają w nim prace literackie i historyczne ${ }^{56}$. Obok tej tematyki, w niewielkiej ilości, występują publikacje z zakresu geografii, etnografii, historii literatury i innych. W pewnym stopniu świadczy to o różnorodności biblioteki. W czasach Potockiej panie nie ograniczały się już tylko do gromadzenia romansów, a w ogóle wiek XIX przyniósł duże zróżnicowanie bibliotek prywatnych, nie tylko tworzonych przez kobiety ${ }^{57}$. Wśród literatury najwięcej jest różnych odmian powieści. Ten gatunek pogardzany w oświeceniu dynamicznie się rozwijał i zdobywał coraz większe uznanie czytelników. Powieści Potockiej dokładnie ilustrują ten proces. Drugą, bardzo liczną grupę tworzą pozycje mówiące o wydarzeniach, dzisiaj historycznych, które rozegrały się za życia Potockiej. Zasięg chronologiczny księgozbioru, lata działalności autorów książek, a także występowanie wielu pierwszych wydań dzieł, prowadzą do wniosku, że

${ }^{54}$ K. Falicka, Literatura francuska. Wiek XIX, [w:] Dzieje literatur europejskich..., s. 696-697.

${ }_{55}$ Współczesna pisarka francuska z domu Corri [Torii], zob. Encyklopedia powszechna. T. 25, Warszawa 1867, s. 527.

${ }^{56}$ K. Maleczyńska, op. cit., s. 198.

${ }^{57} \mathrm{~W}$. Jabłońska, Inwentarze i katalogi biblioteczne w zbiorach rękopiśmiennych Biblioteki Zaktadu Narodowego im. Ossolińskich, „Ze Skarbca Kultury” 1969, z. 20, s. 86-87. 
mamy zbiór książek w znacznej mierze aktualnych. Potocka jawi się jako kobieta o szerokich horyzontach, wyrobiona intelektualnie, zainteresowana nowościami literackimi oraz europejskimi wydarzeniami politycznymi, które oddziaływały również na losy Polski.

\section{ANEKS}

\section{Spis książek Korduli Potockiej}

Wykaz skrótów:

BNF - Bibliothèque Nationale de France,

dostęp: http://www.bnf.fr/fr/collection_et_services/catalogues.html

WorldCat - WorldCat-OCLC, dostęp: htts://world.cat.org/

KP-BJ - Katalog Podstawowy Biblioteki Jagiellońskiej, dostęp: http://pka.bj.uj.edu.pl/

ÖNB - Österreichische Nationalbibliothek, dostęp: http://www.onb.ac.at/

\section{LITERATURA FRANCUSKA}

\section{Balzac, Honoré de (1799-1850)}

Le Médecin de campagne. T. 1-2.

Paryż, L. Mame-Delaunay, 1833.

BNF

\section{Busoni, Philippe (1804-1883)}

D’Egmont. Paris et Saint-Cloud au 18 brumaire.

Paryż, H. Fournier jeune, 1832.

$\mathrm{BNF}$

\section{Collin de Plancy, Clotilde-Marie (1790?-...)}

Un Homme.

Paryż, Bohaire, 1832.

$\mathrm{BNF}$

\section{Davin, Félix (1807-1836)}

Le Crapaud. Romain espagnol 1823. T. 2.

Paryż, L. Mame-Delaunay, 18.

BNF

\section{Debraux, Paul-Émile (1796-1831)}

Les Barricades de 1830.

Bruksela, Louis Hauman, 1830.

BNF 


\section{Delille, Jacques (1738-1813)}

L'Homme des champs ou Les Géorgiques françoises.

Bazylea, Jacques Decker, 1800.

BNF

7. Delille, Jacques (1738-1813)

L'Imagination. T. 2.

Paryż, Giguet et Michaud, 1806.

BNF

8. Ducange, Victor (1783-1833)

Ludovica ou Le Testament de Waterloo. T. 1-6.

Paryż, Charles Gosselin ; Lecointe, 1830.

BNF

9. Genlis, Stéphanie-Félicité Du Crest (1746-1830; comtesse de) Les Athées conséquens, ou Mémoires du commandeur de Linanges. Paryż, C. J. Trouvé, 1824.

$\mathrm{BNF}$

10. Genlis, Stéphanie-Félicité Du Crest (1746-1830; comtesse de) Bélisaire.

Paryż, Maradan, 1808.

$\mathrm{BNF}$

11. Genlis, Stéphanie-Félicité Du Crest (1746-1830; comtesse de)

Le Comte de Corke. T. 1-2.

Wiedeń, Schrämbl, 1813.

WorldCat

12. Genlis, Stéphanie-Félicité Du Crest (1746-1830; comtesse de)

Le Dernier voyage de Nelgis ou Mémoires d'un vieillard. 1-2.

Paryż, Roux, 1828.

WorldCat

13. Kock, Paul de (1791-1871)

L'Homme de la nature et l'homme policé. T. 1-5.

Paryż, Gustave Barba, 1831.

WorldCat

14. Lacroix, Paul (1806-1884)

Un Divorce.

Paryż, Eugene Renduel, 1832.

BNF 
15. Lamothe-Langon, Étienne-Léon de (1786-1864)

Le Duc et le page. Roman de moeurs. T. 1-4.

Paryż, Lachapelle, 1831.

BNF

16. Lesage, Alain-René (1668-1747)

Histoire de Gil Blas de Santillane. T. 1-5.

Wiedeń, Schrämbl, 1812.

KP-BJ

\section{Mardelle, Jean-Baptiste}

Gustave Wasa, ou la Suède au seizième siècle. Romain historique. T. 1-5.

Paryż, Timothee Dehaye, 1830.

BNF

18. Masson, Michel (1800-1883)

Thadéus le ressuscité. T. 1-2.

Paryż, Ambroise Dupont, 1833.

WorldCat

19. Méré, Élisabeth Brossin de (1751-1829)

Les Forges mystérieuses, ou L'Amour alchymiste. T. 1-4.

Paryż, L'Auteur, 1800-1801.

BNF

20. Montigny, Louis Gabriel (zm. 1846)

Le Colonel Duvar, fils naturel de Napoléon. T. 1-4.

Paryż, Baudouin frères, 1827.

BNF

21. Montrol, François Mongin de (1799-1862)

Annuaire anecdotique, ou Souvenirs contemporains. Janvier, 1826.

Paryż, Ponthieu, 1826.

BNF

22. Mouhy, Charles de Fieux, chevalier de (1701-1784)

Lamekis, ou Les Voyages extraordinaires d'un Égyptien dans la terre intérieure $[\ldots]$.

Amsterdam; Paris, [s.n.], 1787-1788.

BNF

23. Petit manuel anecdotique, ou Recueil des anecdotes les plus spirituelles philosophiques et morales contemporaines. 
Paryż, Heideloff et Campe, 1831.

WorldCat

\section{Regnault-Warin, Jean-Joseph (1775-1844)}

Madame de Maintenon. 1-4.

Paryż, Fréchet, 1806.

WorldCat

\section{Ricard, Auguste (1799-1841)}

Le Cocher de fiacre, ou Quarante ans sur le pavé de Paris. Roman moeurs. T. 1-4. Paryż, Lecointe et Durey, 1828.

$\mathrm{BNF}$

26. Ricard, Auguste (1799-1841)

La Vivandière de la Grande armée, ou Encore une contemporaine. T. 1.

Paryż, Lecointe, 1829.

BNF

\section{Salgues, Jacques Barthélemy (1760-1830)}

Préjugés des réputations.

Paryż, Mme Ve Lepetit, 1830.

WorldCat

28. Sand, George (1804-1876)

Indiana. T. 1-2.

Paryż, Henri Dupuy, 1832.

$\mathrm{BNF}$

29. Sand, George (1804-1876)

Lélia. T. 1-2.

Paryż, Henri Dupuy, 1833.

BNF

30. Sarrazin, Adrien de (1776-1852)

Bardouc, ou Le Pâtre du Mont-Taurus.

Paryż, Urbain Canel, 1825.

BNF

31. Sarrazin, Adrien de (1776-1852)

Le Caravansérail, ou Recueil de contes orientaux traduit sur un manuscrit persan.

T. 1-2. 
Paryż, Urbain Canel, 1825.

BNF

32. Sarrazin, Adrien de (1776-1852)

Contes nouveaux et nouvelles. T. 1-2.

Paryż, Urbain Canel, 1825.

BNF

33. Soumet, Alexandre (1788-1845)

Une fête de Néron. Tragédie en cinq actes. 2 Ed.

Paryż, J.-N. Barbra, 1830.

BNF

34. Staël-Holstein, Germaine de (1766-1817)

Delphine. T. 1-3.

Paryż, Maradan, 1802.

WorldCat

35. Suard, Amélie (1743-1830)

Madame de Maintenon peinte par elle-même. T. 1-2.

Paryż, Janet et Cotelle, 1828.

BNF

36. Touchard-Lafosse, Georges (1780-1847)

Le Bosquet de Romainville. T. 1-2.

Paryż, Charles Lachapelle, 1833.

BNF

37. Trembicka, Franciszka (zm. 1869)

Le dernier des Gibelins.

Paryż, Lecointe et Pougins, 1834.

BNF

INNE LITERATURY

38. Aikin, Lucy (1781-1864)

Mémoires sur la cour d'Élisabeth. T. 1-3.

Paryż, A. Sautlet, 1827.

BNF

39. Bulwer Lytton, Edward George (1803-1873)

Devereux. T. 1-3.

Paryż, Mame et Delaunay-Vallée, 1829.

WorldCat 
40. Bulwer Lytton, Edward George (1803-1873)

Les Pélerins aux bords du Rhin. T. 1-2.

Paryż, H. Fournier, 1834.

BNF

41. Cooper, James Fenimore (1789-1851)

Le Bourreau de Berne, ou L'Abbaye des Vignerons. T. 1-4.

Paryż, Charles Gosselin, 1823.

KP-BJ

42. Cooper, James Fenimore (1789-1851)

Le corsaire rouge. T. $1-4$.

Paryż, Charles Gosselin, 1828.

WorldCat

43. Cooper, James Fenimore (1789-1851)

Précaution, ou Le Choix d'un mari. T. 1-4.

Paryż, Charles Gosselin, 1825.

WorldCat

44. Contes chinois. T. 1-3

Paryż, Moutardier, 1827.

BNF

45. Cumberland, Richard (1732-1811)

Arundel. T. 1-2.

Paryż, Maradan, 1798.

WorldCat

46. Hamilton, Mary (Lady; 1739-1816)

La Famille du duc de Popoli. Mémoires de M. De Cantelmo, son frère. T. 1-2.

Wiedeń, Schrämbl, 1818.

ÖNB

\section{Bertin, Théodore-Pierre (1751-1819)}

Les Rieursanglais, ou Supplément à l'Encyclopédie comique. T. 1-2.

Paryż, l'Éditeur 1 Rue de la Sonnerie, 1801.

BNF

48. Scott, Walter (1771-1832)

Charles le Téméraire, ou Anne de Geierstein, la fille du brouillard. Roman historique. T. 1.

Paryż, Charles Gosselin, 1829.

BNF 
49. Scott, Walter (1771-1832)

Histoire d'Écosse racontée par un grand-père à son petit-fils [...]. T. 1-3.

Paryż, Charles Gosselin, 1828.

$\mathrm{BNF}$

50. Scott, Walter (1771-1832)

Woodstock. T. 1-4.

Paryż, Charles Gosselin, 1826.

$\mathrm{BNF}$

\section{Velde, Carl Franz van der (1779-1824)}

Les Anabaptistes. Histoire du commencement du XVI siècle, d'après les chroniques et les documents du temps.

Paryż, J. Renouard: C. Gosselin, 1826.

$\mathrm{BNF}$

\section{Velde, Carl Franz van der (1779-1824)}

Les Patriciens. Histoire de la fin du XVIe siècle, d'après d'anciennes chroniques.

Paryż, J. Renouard : C. Gosselin, 1826.

$\mathrm{BNF}$

\section{Wieland, Christoph Martin (1733-1813)}

Aristippe et quelques-uns de ses contemporains. T. 2-7.

Paryż, Poignée, 1802-1805.

WorldCat

\section{DZIEŁA HISTORYCZNE}

54. Année, Antoine (ur. 1770)

L'empereur Napoléon et M. Le Duc de Rovigo, ou Le Revers des médailles.

Paryż, P. Mongie, 1828.

$\mathrm{BNF}$

\section{Arpentigny, Stansislas d' (1791-1864)}

Voyage en Pologne et en Russie par un prisonnier de Guerre de la garnison de Dantzick en 1813 et 1814.

Paryż, Ambroise Dupont, 1828.

BNF

\section{Barante, Prosper Brugière (1782-1866)}

Histoire des ducs de Bourgogne de la maison de Valois, 1364-1477. T. 1-10. 
Paryż, Ladvocat, 1824-1826.

$\mathrm{BNF}$

57. Biographie étrangère, ou Galerie universelle, historique, civile, militaire, politique et littéraire; contenant les portraits politiques de plus de trois mille personnages célèbres [...] par une Société de gens de lettres. T. 1-2.

Paryż, Alexis Eymery, 1819.

BNF

58. Briquet, Marguerite Ursule Fortunée Bernier (1782-1815)

Dictionnaire historique, littéraire et bibliographique des Françaises et des étrangères naturalisées en France connues par leurs écrits, ou par la protection qu'elles ont accordée aux gens de lettres [...].

Paryż, Treuttel et Würtz,1804.

BNF

59. Campan, Madame (1752-1822)

Mémoires sur la vie privée de Marie-Antoinette [...]. T. 1-3.

Paryż, Mongie aîné: Baudouin frères, 1823.

BNF

60. Caze, Jean-François (1781-1851)

Réfutation de „La vie de Napoléon” sir Walter Scott. T. 1-2.

Paryż, Baudouin frères, 1827.

BNF

61. Chateaubriand, François-René de (1768-1848)

De la Nouvelle proposition relative au bannissement de Charles X et de sa famille, ou Suite de mon dernier écrit „De la Restauration et de la monarchie élective”.

Paryż, Le Normant fils, 1831.

$\mathrm{BNF}$

62. Conspiration de Russie. Rapport de la Commission d'enquête de St-Pétersbourg à S. M. l'empereur Nicolas 1er sur les sociétés secrètes découvertes en Russie, et prévenues de conspiration contre l'État.

Paryż, Ponthieu, 1826.

BNF

63. Dainville, D.

Beautés de l'histoire du Canada, ou Époques remarquables, traits intéressans, mœurs, usages, coutumes des habitans du Canada, tant indigènes que colons, depuis sa découverte jusqu'à ce jour. Paryż, Bossange frères, 1821.

BNF 
64. Dangeau, Philippe de Courcillon (1638-1720; marquis de)

Abrégé des mémoires, ou Journal du Marquis de Dangeau. T. 1-4.

Paryż, Treuttel et Würtz, 1817.

BNF

65. Événemens de Paris des 26, 27, 28 et 29 juillet 1830 par plusieurs témoins oculaires.

Paryż, Audot, 1830.

BNF

66. Fryderyk II Wielki (król Prus; 1712-1786)

Caractère des personnages les plus marquans dans les différentes cours de l'Europe [...]. T. 1 .

Paryż, Leopold Collin, 1808.

BNF

67. Galotti, Antonio (1786-1849?)

Mémoires de A. Galotti, officier Napolitain, condamné trois fois à mort.

Paryż, Moutardier, 1831.

BNF

68. Genlis, Stéphanie-Félicité Du Crest (1746-1830; comtesse de)

Mémoires inédits de madame la Comtesse de Genlis sur le dix-huitième siècle et la révolution française, depuis 1756 jusqu'à nos jours. T. 1-10.

Bruksela, H. Tarlier, 1825.

WorldCat

69. Irving, Washington (1783-1859)

Histoire de la vie et voyages de Christophe Colomb. T. 1-4.

Paryż, Charles Gosselin, 1828.

BNF

70. Peignot, Gabriel (1767-1849)

De la Maison royale de France, ou Précis généalogique et anecdotique sur la famille de Bourbon [...], depuis Saint-Arnoul, en 596 [...].

Paris, Renouard, 1815.

BNF

71. Pradt, Dominique Dufour (1759-1837; baron de)

Du Congrès de Vienne. T. 1-2.

Paryż, Deterville, 1815.

BNF 


\section{Pradt, Dominique Dufour (1759-1837; baron de)}

Des Colonies et de la révolution actuelle de l'Amérique. T. 1-2.

Paryż, F. Béchet, 1817.

BNF

\section{Proyart, Liévin-Bonaventure (1743?-1808)}

Louis XVI détrôné avant d'être roi, ou Tableau des causes nécessitantes de la Révolution française et de l'ébranlement de tous les trônés .

Londyn, [s. n.], 1800.

$\mathrm{BNF}$

\section{Saint-Elme, Ida (1776-1845)}

Mémoires d'une contemporaine, ou Souvenirs d'une femme sur les principaux personnages de la République, du Consulat, de 1'Empire [...]. T. 1-7.

Paryż, Ladvocat, 1827-1828.

BNF

\section{Saint-Prosper, Auguste}

Louis XVIII et Napoléon. Dialogue suivi de plusieurs autres.

Paryż, N. Pichard, 1828.

BNF

76. Salvandy, Narcisse-Achille de (1795-1856)

Histoire de Pologne avant et sous le roi Jean Sobieski. T. 1-3.

Paryż, A. Sautelet et Cie, 1829.

BNF

77. Santo-Domingo, Joseph-Hippolyte de (1785-1832)

Les Jésuites en action sous le ministère Villèle.

Paryż, Ponthieu, 1828.

$\mathrm{BNF}$

78. Scott, Walter (1771-1832)

Vie de Napoléon Buonaparte. [T. 1-18].

Paryż, Charles Gosselin : Treuttel et Würtz, 1827.

WorldCat

79. Ségur, Louis-Philippe de (1753-1830)

Histoire de Napoléon et de la grande armée pendant l'année 1812. T. 1-4.

Berlin, Theod. Chr. Fred. Enslin., 1827.

WorldCat

80. Sevelinges, Charles-Louis de (1767-1831)

La Contemporaine en miniature, ou Abrégé critique de ses mémoires. 
Paryż, J. G. Dentu, 1828.

BNF

\section{Sevelinges, Charles-Louis de (1767-1831)}

Le Duc de Rovigo en miniature, ou Abrégé critique de ses mémoires.

Paryż, J. G. Dentu, 1828.

$\mathrm{BNF}$

\section{DZIEŁA O RÓŻNEJ TREŚCI}

\section{Brisset, Mathurin-Joseph (1792-1856)}

Madrid, ou Observations sur les moeurs et usages des Espagnols au commencement du XIXe siècle [...]. T. 1-2.

Paryż, Pillet aîné, 1825.

BNF

\section{Genlis, Stéphanie-Félicité Du Crest (1746-1830; comtesse de)}

Dictionnaire critique et raisonné des étiquettes de la cour, des usage du monde, des amusemens, des modes, des moeurs [...].

Paryż, P. Mongie aîne, 1818.

BNF

\section{Johanneau, Éloi (1770-1851)}

Rhétorique et poétique de Voltaire, appliquées aux ouvrages des siècles de Louis XIV et de Louis XV, ou Principes de littérature [...].

Paryż, Alexandre Johanneau, 1828.

BNF

\section{Keate, George (1729-1797)}

Relation des îles Pelew, situées dans la partie occidentale de 1'Océan Pacifique.

T. 1-2.

Paryż, Le Jay et Maradan, 1788.

BNF

\section{Lévi Alvarès, David (1794-1870)}

Énigmes historiques, géographiques, mythologiques, iconologiques, biographiques [...], à l'usage des collèges et des maisons d'éducation.

Paryż, Antoine-Augustin Renouard, 1823.

BNF

\section{Staël-Holstein, Germaine de (1766-1817)}

De 1'Allemagne. T. 1-3. 
Paryż, H. Nicolle, 1814.

BNF

88. Stedman, John Gabriel (1744-1797)

Voyage à Surinam et dans l'intérieur de la Guiane [...]. T. 1-3.

Paryż, F. Buisson, 1798.

BNF

89. Taschereau, Jules-Antoine (1801-1874)

Histoire de la vie et des ouvrages de Molière.

Paryż, Ponthieu, 1825.

$\mathrm{BNF}$

90. Weiss, François Rodolphe de (1751-1802)

Principes philosophiques, politiques et moraux. T. 1-2.

Genewa, J. J. Paschoud, 1806.

$\mathrm{BNF}$

IRENA GRUCHAŁA

BOOKS FROM THE COLLECTION OF KORDULA POTOCKA NÉE KOMOROWSKA IN HELENA DĄBCZAŃSKA'S LIBRARY

Summary

The books from the household collection of Helena Dąbczańska (1863-1956), a famous Lviv collector, are currently preserved in the Central Library of the Academy of Fine Arts and in the Jagiellonian Library in Cracow. The research into the collection has identified portions of the collection that previously were part of libraries collected in aristocratic households. The current article discusses 90 books that were once in possession of Kordula Potocka (1764 - after 1837), wife of voivode of Bełz, Teodor Potocki (1730-1812). The collection is an example of a library created at the turn of the eighteenth and nineteenth centuries, at a time when upper-class women were increasingly interested in books: they read intensely and created private libraries, in which love stories were being gradually replaced by a variety of fiction and non-fiction. Kordula Potocka's choice of books reflects cultural developments of the period. As a lady of fashion and a powerful magnate's wife, she would read books in French published abroad. Like other private libraries during the period of the Partitions of Poland, Potocka's collection is dominated by works of fiction and books on history. In the former category, many varieties of the novel are represented. The novel, a genre previously despised during the Enlightenment period, in Potocka's time was developing and gaining wider readership. The novels gathered by Potocka are an accurate representation of this literary development. Another vast category are books concerning events that occurred during Potocka's lifetime. The chronological range of the collection, the authors' periods of activity and the presence of many first editions suggest that the volumes in this category are for the most part contemporaneous with current affairs of the period. 